EISSN: 2706-7939 ISSN: 2077-4508

DOI: $10.36632 / \mathrm{ije} / 2021.10 .1 .4$

Journal homepage: www.curresweb.com

Pages: 33-46

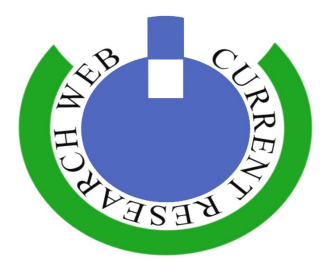

\title{
Chemical, Physical and Sensory Evaluation of Low Fat Beef Burger with Carboxymethyl Cellulose Produced From Rice and Wheat Bran
}

\author{
A. M. Sorour ${ }^{1}$, M. A. Salem ${ }^{2}$, S.G. Arafa, ${ }^{3}$ and M.A. El-Bana ${ }^{1}$ \\ ${ }^{1}$ Food Tech. Res. Inst., Agric. Res. Center, Giza, Egypt \\ ${ }^{2}$ Food Sci. and Tech. Dept., Fac. of Agric. Tanta Univ., Egypt. \\ ${ }^{3}$ Food Sci. and Tech. Dept., Fac. of Agric. Kafer ELshekh Univ., Egypt
}

Received: 16 December 2020 Accepted: 28 February 2021 Published: 05 March 2021

\begin{abstract}
This investigation was carried out to study the possibility of produce of carboxymethyl cellulose (CMC) from rice and wheat bran and used as fat replacers in preparing low fat beef burger was added by substitution of fat at levels of 1.0,1.5 and 2.0\%. Characterizations of CMC were analyzing by the spectra of FTIR, Degree of substitution (DS), water holding capacity, oil holding capacity and swelling capacity. Furthermore, gross chemical composition, physical properties, cooking characteristics of beef burger were determined. Results indicated that, Rice bran had significantly the highest content of crude protein, ether extract and cellulose content compared with wheat bran on contrast, wheat bran had a significantly higher percentage of ash , total carbohydrate and hemicellulose (11.91, 60.48and 49.85\% , respectively) than that of rice bran. The $\mathrm{CMC} \%$, Degree of substitution (DS), water holding capacity, oil holding capacity and swelling capacity of CMC produced from rice bran are significantly higher than that of wheat bran. addition to, CMC increase the amount of moisture, carbohydrates and crude fiber and decrease the amount of fat in compare with control beef burger sample. Statistical analysis for physical properties indicated that there were a significant differences in both shrinkage and diameter reduction, while no differences were observed in Texture Profile Analysis( TPA) for beef burger formulas prepared with CMC compared with control beef burger. So this research suggests that CMC is effective in improving physical, chemical and functional properties of beef burger.
\end{abstract}

Keywords: low fat beef burger, fat replacer, carboxymethyl cellulose, rice bran, wheat bran

\section{Introduction}

In recent years, the agro waste materials have created intensive research interest of scientists to use in technology development due rich content and poor waste management technology.

One of the potential agro-wastes are rice bran (RB) and wheat bran (wb) which are available in large quantity as food industrial by-products.( Oliveira et al., 2017).

Rice bran is one of the major byproduct generated during the rice milling process. Rice bran represent approximately $8 \%$ of the dry weight of the rice harvest. Rice bran rich in dietary fiber consists of hemicelluloses $21.08 \%$, mainly arabinoxylan, cellulose $33.60 \%$ and lignin $5 \%$ (Hussein and Ibrahim (2019).

Wheat bran is separated from the other parts of the wheat kernel by milling, and the chemical composition of wheat bran predominantly comprises non-starch polysaccharides $38 \%$, starch $19 \%$, protein $18 \%$ and lignin $6 \%$, with the non-starch polysaccharides being approximately $70 \%$ arabinoxylans, approximately $19 \%$ cellulose and approximately $6 \% \beta-(1,3) / \beta-(1,4)$-glucan. (Hussein and Ibrahim, 2019 and Manali and Dr Savita., 2019). So, rice bran and wheat bran are a cheap and rich source of cellulose.

Cellulose can hardly exist in pure form but can be found in the plant cell wall with hemicellulose and lignin (Pushpamalar et al., 2006). Its isolation can be possible, utilizing accessible less expensive chemicals that produce physical and chemical properties better than cellulose obtained commercially.

Corresponding Author: A. M. Sorour, Food Tech. Res. Inst., Agric. Res. Center, Giza, Egypt 
It serves as a starting material for the synthesis of carboxymethyl cellulose and its derivatives, cellulose acetate, methylcellulose, cellulose nitrate, and ethyl cellulose. Being a polysaccharide, it is formed as a result of the repeating unit of D-glucose, linked by glycosidic linkage $\beta$ (1-4). The presence of three reactive hydroxyl groups $(\mathrm{C} 2, \mathrm{C} 3$, and $\mathrm{C} 6)$ on each glucan unit of cellulose makes it relatively easy to modify, Purified CMC is a white to cream colored, tasteless, odorless, free-flowing powder and used in a variety of industries including the food, detergents, personal care, pharmaceutical etc.( Mondal, et al., 2015).

Recent studies have established relationship between meat consumption and increased risk of suffering serious health disorders such as colorectal cancer and coronary-heart diseases. There is an advice from health organizations to reduce the amount of dietary fat to reduce the risks of chronic disease such as coronary heart disease, some types of cancer and obesity (Haward et al., 2006).

Fat is an important ingredient in processed meats furthermore, Fat plays an important role in the texture and water-binding capacity (WBC) of meat products, the decrease on the fat content usually negatively affects final product appearance, flavor, and texture (Furlán, et al., 2014).The major problem in acceptability of low-fat processed meat products is the decline in palatability with fat reduction (Mansour and Khalil, 1997).

Recent studies have shown that some ingredients can be added as fat replacers in meat products, such as carboxymethyl cellulose (CMC) (Furlán et al., 2014; Gibis et al., 2017).The abilities of CMC acting as a fat replacer, emulsion stabilizer and thickener have been explored in dairy and bakery products as well as in low-fat meat products, such as emulsified sausages and burger patties (Ulu, 2005). So, this research was aimed to evaluate the effect of addition different levels of carboxymethyl cellulose produced from rice and wheat bran as a fat replacers on physical, chemical characteristics and sensory evaluation of low fat beef burger.

\section{Materials and Methods}

\subsection{Materials}

\subsubsection{Agro-industrial by-products:}

A. Rice bran (RB) variety Sakha 101 were obtained from the Rice Research and Training Center(RRTC), Sakha, Kafer El-Sheikh, Egypt, Season 2019 and stored in deep freeze at $-20^{\circ} \mathrm{C}$ until further use.

B. Wheat bran (Wb) was purchased from Delta Middle and West Milling Company, Tanta, Egypt, Season 2019 and stored in deep freeze at $-20^{\circ} \mathrm{C}$ until further use.

C. Beef meat and other ingredients used to prepare beef burger (spices mixture, garlic, onion, sunflower oil and salt) were obtained from local market at Kafr El-Sheikh city, Egypt.

D. Chemicals: All chemicals used in current study were obtained from El-Gomhoria Company for Chemical and Drugs Tanta, Egypt.

\subsection{Methods}

\subsubsection{Preparation of Agro-industrial by-products}

A. Rice and wheat bran were air dried at $40^{\circ} \mathrm{C}$ for $1 \mathrm{hr}$. and ground into fine power and stored in the polyethylene bags in the deep freezer at $-20^{\circ} \mathrm{C}$ until use (Salem et al ., 2018).

B. Extraction of oil from rice and wheat bran were Implemented using the method described by A.O.A.C. (2005).

C. Elimination of starch from rice and wheat bran described by Zhou et al. (2010).

D. Removal of protein from destarched and defatted rice and wheat bran according to Chanput et al. (2009).

E. Extraction of cellulose from deprotein, destarched and defatted rice and wheat bran as described by (Adinugraha et al., 2005)

F. Production of sodium carboxymethyl cellulose from rice and wheat bran using the method reported by Adinugraha et al., (2005). 


\subsection{Gross chemical composition of Agro-industrial by-products}

Moisture, crude protein, ether extract, ash, crude fiber and of samples were determined according to A.O.A.C. (2005).

Total carbohydrates content was calculated by subtracting protein, ash and ether extract contents from the total mass of 100 as reported by Tadrus (1989).

Lignin content in the investigated materials was determined according to the method described by Bledzki et al. (2010).

Acid insoluble ash (silica) was determined according to the method of A.O.A.C. (2005).

\subsection{Characterization $\mathrm{CMC}$}

A. The infrared spectroscopic analysis was carried out for commercial CMC and CMC produced from rice and wheat bran using the $\mathrm{KBr}$ method described by Pushpamalar et al. (2006).

B. Determinations of degree of substitutions of samples were determined according to the methods of Pushpamalar et al. (2006).

C. Determination of $\mathrm{NaCl}$ content of CMC was carried out by ASTM. (2003)

D. Swelling Capacity was determined simultaneous as the hydration capacity using the method of Okhamafe et al. (1991).

E. Water Solubility Index (WSI) of Carboxymethyl cellulose was determined as described by Anderson and Sefa-dadeh (2001).

F. The $\mathrm{pH}$ of the sample was determined as that of the supernatant after shaking $1 \mathrm{~g}$ in $30 \mathrm{ml}$ of distilled water for $10 \mathrm{~min}$ with a $\mathrm{pH}$ meter (Ejikeme, 2008).

G. Water holding capacity (WHC) and oil-holding capacity (OHC):-

Twenty-five milliliters of distilled water or commercial olive oil were added to $1 \mathrm{~g}$ of dry sample, stirred and incubated at $40^{\circ} \mathrm{C}$ for $1 \mathrm{~h}$. After centrifugation, the residue was weighed and WHC and $\mathrm{OHC}$ calculated as $\mathrm{g}$ water or oil per g of dry sample respectively (Larrauri et al. 1996).

\subsection{Preparation of beef burger and their formulae}

Beef burger samples were formulated according to Aleson-Carbonell et al. (2005) and the ingredients tabulated in table (A). Burger formulas were made using a petri dish to obtain round discs $9 \mathrm{~cm}$ diameter and $1 \mathrm{~cm}$ thickness.

The prepared burgers were packaged by individually in polyethylene film to help maintaining the shape of burger prior to freezing. The samples were frozen at $-18{ }^{\circ} \mathrm{C}$ prior to analysis.

Table A: Ingredients of prepared beef burgers containing carboxymethyl cellulose produced from rice and wheat bran at levels $(1.0,1.5$ and $2.0 \%)$.

\begin{tabular}{lcccccccc}
\hline Ingredients & $\begin{array}{c}\text { Level } \\
\text { addition }\end{array}$ & $\begin{array}{c}\text { Beef } \\
\text { Meat }\end{array}$ & $\begin{array}{c}\text { Beef Back } \\
\text { Fat }\end{array}$ & $\begin{array}{c}\text { Ice } \\
\text { water }\end{array}$ & $\begin{array}{c}\text { Spice } \\
\text { mixture }\end{array}$ & $\begin{array}{c}\text { Dried } \\
\text { onion }\end{array}$ & $\begin{array}{c}\text { Dried } \\
\text { garlic }\end{array}$ & NaCl \\
\hline Control & - & 65 & 15 & 10.5 & 1.5 & 3 & 3 & 2 \\
\hline \multirow{2}{*}{ CMC $_{1}$} & 1.0 & 65 & 14 & 10.5 & 1.5 & 3 & 3 & 2 \\
& 1.5 & 65 & 13.5 & 10.5 & 1.5 & 3 & 3 & 2 \\
\hline \multirow{3}{*}{$\mathbf{C M C}_{2}$} & 2.0 & 65 & 13 & 10.5 & 1.5 & 3 & 3 & 2 \\
& 1.0 & 65 & 14 & 10.5 & 1.5 & 3 & 3 & 2 \\
& 1.5 & 65 & 13.5 & 10.5 & 1.5 & 3 & 3 & 2 \\
\hline
\end{tabular}

$\mathbf{C M C}_{1}=$ carboxymethyl cellulose produced rice bran $\mathbf{C M C}_{2}=$ carboxymethyl cellulose produced wheat bran

\subsubsection{Cooking of Beef Burger}

The beef burger studied samples were cooked using an electrical grill (Arcelik Mini Firin, Turkey) at $300{ }^{\circ} \mathrm{C}$ (the distance between heat source and the sample was $4 \mathrm{~cm}$ ) for a total of $10 \mathrm{~min}, 6$ min one side and 4 min in the other side (Turhan et al., 2005).

\subsection{Physical properties and feder value}

\subsubsection{Water Holding Capacity (WHC) and Plasticity}

Water Holding Capacity (WHC) was measured using the method of El-Seesy (2000) by the following equations: 


$$
\text { Free water }(\%)=\frac{\text { Total surface area- Meat film area, } \mathrm{mm}(6.11)}{\text { Total moisture }(\mathrm{mg}) \text { in meat sample }} \times 100
$$

WHC $(\%)=100$ - free water

Plasticity $\left(\mathrm{cm}^{2}\right)=$ Meat film area (Internal area)

\subsection{Texture indices}

Protein water coefficient (PWC) and protein-water-fat coefficient (PWFC) were calculated according to Tsolaze, (1972) using the following equations:

$$
P W C=\frac{\% \text { Protein }}{\% \text { water }} \quad P W F C=\frac{\% \text { Protein }}{\% \text { water }+ \text { fat }}
$$

Feder value which is used for assessing one of the quality attributes in meat was calculated according to Pearson, (1970) using the following equation:

$$
\text { Feder value }=\frac{\% \text { Water }}{\% \text { Organic non fat }}
$$

Where $\%$ organic nonfat $=100-(\%$ Moisture $+\%$ Fat $+\%$ Ash $)$.

\subsection{Cooking characteristics}

\subsubsection{Texture Profile Analysis}

Texture was determined in Food Technology Research. Institute, Agricultural Research Center Giza- Egypt, by a universal testing machine (Cometech, B type, Taiwan) provided with software. An Aluminum $25 \mathrm{~mm}$ diameter cylindrical probe was used in a "Texture Profile Analysis" (TPA) double compression test to penetrate to $50 \%$ depth, at $1 \mathrm{~mm} / \mathrm{s}$ speed test. hardness $\left(\mathrm{N} / \mathrm{cm}^{2}\right)$, gumminess $\left(\mathrm{N} / \mathrm{cm}^{2}\right)$, chewiness $\left(\mathrm{N} / \mathrm{cm}^{2}\right)$, cohesiveness (ratio), and springiness $(\mathrm{cm})$ were calculated from the TPA graphic (Bourne, 2003).

\subsubsection{Shrinkage}

Shrinkage percentage was calculated as described by A.M.S.A, (1995) as follows:

$$
\% \text { Shrinkage }=\frac{(\text { Raw thickness }- \text { Cooked thickness })+(\text { Raw diameter }- \text { Cooked diameter })}{(\text { Raw thickness }+ \text { Cooked diameter })} \times 100
$$

\subsubsection{Diameter reduction} equation:

Changes in beef burgers diameter was calculated by Gok et al. (2011) using the following

$$
\% \text { Diameter Reduction }=\frac{\text { Un cooked diameter } \text { - Cooked diameter }}{(\text { Un cooked diameter }} \times 100
$$

\subsubsection{Cooking loss}

Cooking loss of the beef burger was calculated according to A.M.S.A, (1995) using the following equation:

$$
\% \text { Cooking loss }=\frac{\text { Raw sample weight }(g) \text {-Cooked sample weight }(g)}{\text { Raw sample weight }(g)} \times 100
$$

\subsubsection{Cooking yield}

Cooking yield of the beef burger was determined by measuring the weight of three burgers for each treatment/batch Gok et al., (2011) and calculating weight differences for burgers before and after cooking, as follows:

$$
\% \text { Cooking yield }=\frac{\text { Cooked weight }(g)}{\text { Raw weight }(g)} \times 100
$$




\subsubsection{Sensory evaluation}

The Sensory characteristics of the cooked burger samples were carried out by well-trained 20 panelists of Food Technology Research Institute (FTRI). Panelists were asked to evaluate color, texture, taste, appearance and overall acceptability, of cooked samples according to the method described by (A.M.S.A, 1995).

\section{Statistical analysis}

Data were analyzed according to Steel and Torrie (1980) procedures (Duncan's multiple range test DMRT).

\section{Results and Discussions}

\subsection{Proximate chemical composition of rice and wheat bran}

Proximate chemical composition of rice and wheat bran are given in Table (1). The obtained results indicated that, rice bran had significantly higher contents of crude protein, ether extract, crude fiber and cellulose than rice hull ( $14.30,18.00,14.13$, and $23.45 \%$, respectively) compared to that of wheat bran . Meanwhile, wheat bran contained higher amount of ash, total carbohydrate and hemicellulose (11.91, 60.48 and $49.85 \%$, respectively) than that of rice bran $(8.90,44.67$ and $28.11 \%$ respectively). Also, rice bran contain more moisture content $(8.30 \%)$ than the wheat bran $(8.12 \%)$, although the difference is not significant. The obtained results agree partially with those of El-Sharnouby et al. 2012, Salem et al. (2018) and Hussein and Ibrahim (2019).

Table 1: Gross chemical composition of rice and wheat bran on dry weight basis.

\begin{tabular}{|c|c|c|c|}
\hline Component & Samples & Rice bran & Wheat bran \\
\hline Moisture & & $8.30^{\mathrm{a}} \pm 0.12$ & $8.12^{a} \pm 0.22$ \\
\hline Crude protein & & $14.30^{\mathrm{a}} \pm 0.19$ & $10.30^{b} \pm 0.12$ \\
\hline Ether extract & & $18.00^{\mathrm{a}} \pm 0.08$ & $6.90^{\mathrm{b}} \pm 0.10$ \\
\hline Ash content & & $8.90^{b} \pm 0.12$ & $11.91^{\mathrm{a}} \pm 0.13$ \\
\hline Crude fiber & & $14.13^{\mathrm{a}} \pm 0.18$ & $10.41^{b} \pm 0.11$ \\
\hline Carbohydrate* & & $44.67^{b} \pm 0.84$ & $60.48^{\mathrm{a}} \pm 0.87$ \\
\hline Cellulose & & $23.45^{\mathrm{a}} \pm 0.21$ & $14.45^{\mathrm{b}} \pm 0.18$ \\
\hline Hemicellulose & & $28.11^{b} \pm 0.19$ & $49.85^{\mathrm{a}} \pm 0.10$ \\
\hline Lignin & & $5.60^{\mathrm{a}} \pm 0.13$ & $5.85^{\mathrm{a}} \pm 0.11$ \\
\hline Silica & & $0.96^{\mathrm{a}} \pm 0.04$ & $0.18^{b} \pm 0.09$ \\
\hline
\end{tabular}

Each value is an average of three determinations \pm standard deviation

Values followed by the same letter in rows are not significantly different at $\mathrm{P}<0.05$ Carbohydrate* were calculated by differences

\subsection{Physicochemical characteristics of carboxymethyl cellulose}

Physicochemical properties of carboxymethyl cellulose produced from rice and wheat bran compared to commercial are given in Table (2).

Data in table (2) showed that, carboxymethyl cellulose produced from rice bran, had a high Degree of substitution(DS) and CMC\% (0.78 and 65.8 respectively) following Commercial CMC which had DS and CMC\% (0.76 and 59.75 respectively) then CMC produced from wheat bran which had DS and CMC\% (0.73 and 59.10\%). These results agree with Togrul and Arslan. (2003) Apparent also, from the same Table that, no significant differences were found in moisture, ash content, Nacl \% and PH values between CMC produced from rice and wheat bran and commercial CMC.

These results are supported by Adinugraha et al .(2005) On the other hand, it can be demonstrated that Water holding capacity (WHC) and oil holding capacity (OHC) of carboxymethyl cellulose produced from rice and wheat bran are significantly higher than that of commercial CMC. These results are completely in agree with the those obtained by Latif et al.(2007) and Mondal et al.(2015) From the previous results, it can be deduced that, carboxymethyl cellulose produced from rice bran, was found to have the highest value for swelling capacity $(802.12 \%)$ while carboxymethyl cellulose produced from 
wheat bran showed the least swelling capacity (787.88\%), which is directly proportional to their DS respectively. Meanwhile, carboxymethyl cellulose produced from wheat bran had the least swelling capacity and water solubility index, which is directly proportional to their DS respectively. These results are agree with Ernest et al.(2016) they found that, swelling capacity and water solubility index could have been influenced by their DS .

Table 2: Studying physicochemical characteristics carboxymethyl cellulose produced from rice and wheat bran compared to commercial CMC.

\begin{tabular}{|c|c|c|c|}
\hline $\begin{array}{ll} & \text { Samples } \\
\text { Parameters } & \\
\end{array}$ & $\mathrm{CMC}_{1}$ & $\mathrm{CMC}_{2}$ & Commercial CMC \\
\hline Degree of substitution & $0.78^{a} \pm 0.04$ & $0.73^{\mathrm{ab}} \pm 0.03$ & $0.76^{\mathrm{a}} \pm 0.02$ \\
\hline СМС\% & $65.80^{\mathrm{a}} \pm 0.19$ & $59.10^{b} \pm 0.19$ & $59.75^{b} \pm 0.17$ \\
\hline Moisture & $3.40^{\mathrm{a}} \pm 0.11$ & $3.46^{\mathrm{a}} \pm 0.19$ & $3.42^{\mathrm{a}} \pm 0.14$ \\
\hline Ash content \% & $14.87^{\mathrm{a}} \pm 0.24$ & $14.60^{\mathrm{a}} \pm 0.18$ & $14.70^{\mathrm{a}} \pm 0.23$ \\
\hline WHC g/g & $4.47^{\mathrm{a}} \pm 0.11$ & $4.25^{\mathrm{ab}} \pm 0.09$ & $4.09^{b} \pm 0.12$ \\
\hline OHC g/g & $1.69^{\mathrm{a}} \pm 0.04$ & $1.61^{\mathrm{ab}} \pm 0.03$ & $1.50^{\mathrm{b}} \pm 0.01$ \\
\hline Swelling capacity & $802.12^{\mathrm{a}} \pm 1.94$ & $787.88^{\mathrm{c}} \pm 3.71$ & $800.72^{b} \pm 1.53$ \\
\hline WSI & $56.21^{\mathrm{a}} \pm 0.63$ & $47.00^{c} \pm 0.19$ & $53.65^{\mathrm{b}} \pm 0.25$ \\
\hline NaCL \% & $0.019^{\mathrm{a}} \pm 0.002$ & $0.020^{\mathrm{a}} \pm 0.006$ & $0.022^{a} \pm 0.003$ \\
\hline pH & $6.93^{\mathrm{a}} \pm 0.14$ & $6.97^{\mathrm{a}} \pm 0.13$ & $6.84^{\mathrm{a}} \pm 0.11$ \\
\hline
\end{tabular}

Each value is an average of three determinations \pm standard deviation

Values followed by the same letter in rows are not significantly different at $\mathrm{P}<0.05$

$\mathrm{CMC}_{1}, \mathrm{CMC}_{2}$ as shown in table(A)

\subsection{Infrared spectroscopy (IR)}

The infrared spectra were studied to confirm the substitution reaction in carboxymethylation. The infrared spectra of cellulose, carboxymethyl cellulose produced from rice and wheat bran compared to pure cellulose and commercial carboxymethyl cellulose were presented in Figure 1. Specific vibrations can be found in infrared spectra since this method provide information on molecular vibrations. The cellulose and CMC in each condition were provided the same functional groups. The broad absorption band at $3432 \mathrm{~cm}^{-1}$ is due to the stretching frequency of the $-\mathrm{OH}$ group. The band at $2920 \mathrm{~cm}^{-1}$ is due to $\mathrm{C}-\mathrm{H}$ stretching vibration. The bands around 1420 and $1320 \mathrm{~cm}^{-1}$ are assigned to $-\mathrm{CH}_{2}$ scissoring and $\mathrm{OH}$ bending vibration, respectively.

The band at $1060 \mathrm{~cm}^{-1}$ is due to $-\mathrm{CH}-\mathrm{O}-\mathrm{CH}_{2}$ stretching (Pushpamalar et al. 2006; Rachtanapun et al. 2007) From the representative spectrum of carboxymethyl cellulose produced from rice and wheat bran compared to commercial carboxymethyl cellulose, the strongest absorbance were at 1608, 1419 and $1055 \mathrm{~cm}^{-1}$. This result was indicated the presence of carboxymethyl substituent from CMC synthesis at $\mathrm{COO}-,-\mathrm{CH}_{2}$ and -O- group (Adinugraha et al.2005 and Rachtanapun et al. 2007). According to Adinugraha et al.(2005), carboxyl (COO-) groups as its salts have wave number about $1600-1640 \mathrm{~cm}^{-}$ ${ }^{1}$ and $1400-1450 \mathrm{~cm}^{-1}$. The similar observations have been reported previous by Adinugraha et al. (2005) and Rachtanapun et al. (2007). This result corroborated that CMC could be produced from rice and wheat bran.

\subsection{Proximate chemical composition of beef burger containing $\mathrm{CMC}$ produced from rice and wheat bran with different level of $\mathrm{CMC} \%$ as a fat replacer}

Carboxymethyl cellulose(CMC) produced from rice and wheat bran were used to replace fat with levels $1.0,1.5$ and $2.0 \%$ in beef burger formula, and the resultant uncooked and cooked beef burger were subjected to proximate chemical analysis and the results are shown in Table (3)

It should be noted from the given data that, moisture content of uncooked and cooked beef burger were increased gradually as a function of increasing the percentage of CMC replacement level to beef burger. The increment of moisture content may be due to the capability of CMC rich with fiber to hold more water via preparation and cooking process. These results are in agreement with Kilincceker and Kurt (2018) who stated that dietary fiber source has the capacity to hold three or four times its weight of water. Furthermore, The moisture content of the low fat formulations increased concomitantly with 
Table 3: Proximate chemical composition of beef burger with different levels of carboxymethyl cellulose produced from rice and wheat bran as fat replacer (on dry weight basis).

\begin{tabular}{|c|c|c|c|c|c|c|c|c|c|c|c|c|c|}
\hline \multicolumn{2}{|c|}{$\begin{array}{c}\text { Component } \\
\%\end{array}$} & Moisture & Protein & $\begin{array}{c}\text { Ether } \\
\text { extract }\end{array}$ & Ash & $\begin{array}{c}\text { Crude } \\
\text { fiber }\end{array}$ & *T. C & Moisture & Protein & $\begin{array}{c}\text { Ether } \\
\text { extract }\end{array}$ & Ash & $\begin{array}{c}\text { Crude } \\
\text { fiber }\end{array}$ & $*$ T. C \\
\hline & \multirow[b]{2}{*}{$\mathbf{0}$} & \multicolumn{6}{|c|}{ Uncooked beef burger } & \multicolumn{6}{|c|}{ Uncooked beef burger } \\
\hline & & $\begin{array}{c}59.98 \mathrm{~d} \\
\pm 0.71 \\
\end{array}$ & $\begin{array}{c}42.55 \mathrm{~d} \\
\pm 0.34\end{array}$ & $\begin{array}{c}38.43 \mathrm{a} \\
\pm 0.28 \\
\end{array}$ & $\begin{array}{l}4.01 \mathrm{a} \\
\pm 0.14\end{array}$ & $\begin{array}{l}2.89 \mathrm{~d} \\
\pm 0.09\end{array}$ & $\begin{array}{c}15.01 \mathrm{~b} \\
\pm 0.21 \\
\end{array}$ & $\begin{array}{c}53.64 d \\
\pm 0.49 \\
\end{array}$ & $\begin{array}{c}34.89 \mathrm{~d} \\
\pm 0.25 \\
\end{array}$ & $\begin{array}{c}31.13 \mathrm{a} \\
\pm 0.34\end{array}$ & $\begin{array}{l}5.93 \mathrm{a} \\
\pm 0.11 \\
\end{array}$ & $\begin{array}{l}3.65 \mathrm{~d} \\
\pm 0.15\end{array}$ & $\begin{array}{c}28.05 \mathrm{c} \\
\pm 0.18\end{array}$ \\
\hline \multirow{3}{*}{$\mathrm{CMC}_{1}$} & 1 & $\begin{array}{l}60.54 \mathrm{c} \\
\pm 0.48\end{array}$ & $\begin{array}{c}44.44 \mathrm{c} \\
\pm 0.18\end{array}$ & $\begin{array}{c}36.31 \mathrm{~b} \\
\pm 0.75\end{array}$ & $\begin{array}{l}4.00 \mathrm{a} \\
\pm 0.18\end{array}$ & $\begin{array}{l}4.33 \mathrm{c} \\
\pm 0.16\end{array}$ & $\begin{array}{l}15.25 \mathrm{~b} \\
\pm 0.15\end{array}$ & $\begin{array}{l}55.33 \mathrm{c} \\
\pm 0.37\end{array}$ & $\begin{array}{c}35.66 \mathrm{c} \\
\pm 0.21\end{array}$ & $\begin{array}{c}29.10 \mathrm{~b} \\
\pm 0.36\end{array}$ & $\begin{array}{l}6.24 \mathrm{a} \\
\pm 0.18\end{array}$ & $\begin{array}{l}5.17 \mathrm{c} \\
\pm 0.30\end{array}$ & $\begin{array}{c}29.00 \mathrm{~b} \\
\pm 0.19\end{array}$ \\
\hline & 1.5 & $\begin{array}{c}61.36 \mathrm{~b} \\
\pm 0.69\end{array}$ & $\begin{array}{c}45.46 \mathrm{~b} \\
\pm 0.21\end{array}$ & $\begin{array}{l}34.98 \mathrm{c} \\
\pm 0.33\end{array}$ & $\begin{array}{l}4.06 \mathrm{a} \\
\pm 0.26\end{array}$ & $\begin{array}{l}6.46 \mathrm{~b} \\
\pm 0.13\end{array}$ & $\begin{array}{c}15.50 \mathrm{ab} \\
\pm 0.10\end{array}$ & $\begin{array}{c}56.36 \mathrm{~b} \\
\pm 0.44\end{array}$ & $\begin{array}{c}35.79 \mathrm{bc} \\
\pm 0.19\end{array}$ & $\begin{array}{l}27.93 \mathrm{c} \\
\pm 0.33\end{array}$ & $\begin{array}{l}6.37 \mathrm{a} \\
\pm 0.09\end{array}$ & $\begin{array}{c}7.2 \mathrm{~b} \\
\pm 0.12\end{array}$ & $\begin{array}{c}29.91 \mathrm{ab} \\
\pm 0.13\end{array}$ \\
\hline & 2.0 & $\begin{array}{c}62.42 \mathrm{a} \\
\pm 0.73 \\
\end{array}$ & $\begin{array}{c}46.16 \mathrm{a} \\
\pm 0.19 \\
\end{array}$ & $\begin{array}{c}33.76 \mathrm{~d} \\
\pm 0.21 \\
\end{array}$ & $\begin{array}{l}4.17 \mathrm{a} \\
\pm 0.34 \\
\end{array}$ & $\begin{array}{l}7.45 \mathrm{a} \\
\pm 0.13 \\
\end{array}$ & $\begin{array}{c}15.91 \mathrm{a} \\
\pm 0.19\end{array}$ & $\begin{array}{l}57.45 \mathrm{a} \\
\pm 0.25 \\
\end{array}$ & $\begin{array}{c}36.23 \mathrm{~b} \\
\pm 0.40 \\
\end{array}$ & $\begin{array}{c}26.69 \mathrm{~d} \\
\pm 0.29 \\
\end{array}$ & $\begin{array}{l}6.53 \mathrm{a} \\
\pm 0.41 \\
\end{array}$ & $\begin{array}{l}8.19 \mathrm{a} \\
\pm 0.45 \\
\end{array}$ & $\begin{array}{c}30.55 \mathrm{a} \\
\pm 0.15 \\
\end{array}$ \\
\hline \multirow{3}{*}{$\mathrm{CMC}_{2}$} & 1 & $\begin{array}{l}60.9 \mathrm{c} \\
\pm 0.44\end{array}$ & $\begin{array}{c}44.25 \mathrm{c} \\
\pm 0.26\end{array}$ & $\begin{array}{c}36.52 b \\
\pm 0.12\end{array}$ & $\begin{array}{l}4.04 \mathrm{a} \\
\pm 0.15\end{array}$ & $\begin{array}{l}4.39 \mathrm{c} \\
\pm 0.10\end{array}$ & $\begin{array}{c}15.19 \mathrm{ab} \\
\pm 0.20\end{array}$ & $\begin{array}{l}55.80 \mathrm{c} \\
\pm 0.19\end{array}$ & $\begin{array}{l}35.18 \mathrm{c} \\
\pm 0.21\end{array}$ & $\begin{array}{c}29.41 \mathrm{~b} \\
\pm 0.41\end{array}$ & $\begin{array}{l}6.31 \mathrm{a} \\
\pm 0.21\end{array}$ & $\begin{array}{l}5.31 \mathrm{c} \\
\pm 0.19\end{array}$ & $\begin{array}{c}29.10 b \\
\pm 0.12\end{array}$ \\
\hline & 1.5 & $\begin{array}{c}61.55 \mathrm{~b} \\
\pm 0.31\end{array}$ & $\begin{array}{c}45.43 b \\
\pm 0.31\end{array}$ & $\begin{array}{c}35.05 \mathrm{c} \\
\pm 0.19\end{array}$ & $\begin{array}{l}4.08 \mathrm{a} \\
\pm 0.35\end{array}$ & $\begin{array}{l}6.65 \mathrm{~b} \\
\pm 0.19\end{array}$ & $\begin{array}{c}15.44 \mathrm{ab} \\
\pm 0.24\end{array}$ & $\begin{array}{c}56.36 \mathrm{~b} \\
\pm 0.28\end{array}$ & $\begin{array}{c}35.79 b c \\
\pm 0.41\end{array}$ & $\begin{array}{c}27.93 \mathrm{c} \\
\pm 0.33\end{array}$ & $\begin{array}{c}6.37 \mathrm{a} \pm \\
0.25\end{array}$ & $\begin{array}{l}7.27 \mathrm{~b} \\
\pm 0.27\end{array}$ & $\begin{array}{c}29.91 \mathrm{ab} \\
\pm 0.20\end{array}$ \\
\hline & 2.0 & $\begin{array}{c}62.71 \mathrm{a} \\
\pm 0.29 \\
\end{array}$ & $\begin{array}{c}46.12 \mathrm{a} \\
\pm 0.38 \\
\end{array}$ & $\begin{array}{c}33.78 \mathrm{~d} \\
\pm 0.29 \\
\end{array}$ & $\begin{array}{r}4.21 \mathrm{a} \\
\pm 0.18 \\
\end{array}$ & $\begin{array}{l}7.72 \mathrm{a} \\
\pm 0.15 \\
\end{array}$ & $\begin{array}{c}15.89 \mathrm{a} \\
\pm 0.16 \\
\end{array}$ & $\begin{array}{c}57.73 \mathrm{a} \\
\pm 0.39 \\
\end{array}$ & $\begin{array}{c}36.57 \mathrm{~b} \\
\pm 0.16 \\
\end{array}$ & $\begin{array}{c}26.80 \mathrm{~d} \\
\pm 0.11 \\
\end{array}$ & $\begin{array}{l}6.37 \mathrm{a} \\
\pm 0.26 \\
\end{array}$ & $\begin{array}{l}8.35 \mathrm{a} \\
\pm 0.16 \\
\end{array}$ & $\begin{array}{c}30.36 \mathrm{a} \\
\pm 0.19 \\
\end{array}$ \\
\hline
\end{tabular}

Each value is an average of three determinations

Values followed by the same letter in columns are not significantly different at $\mathrm{P}<0.05$

*Carbohydrates were calculated by difference.

$\mathrm{CMC} 1, \mathrm{CMC} 2, \ldots . . .$. are shown in table $(\mathrm{A})$ 
the increased level of CMC that could be due to fat substituted by moisture in the low fat products (Youssef et al ., 2012) For fat content, which was determined as ether extract, illustrated that the fat content of control beef burger had high amount of fat with significant difference than that of other treatments. Furthermore, fat content of all beef burger containing CMC produced from rice and wheat bran with levels $(1.0,1.5$ and $2.0 \%)$ as fat replacer decreased significantly $(\mathrm{p} \leq 0.05)$ with increasing of replacement level of CMC. These result agree with, Gok et al. (2011).

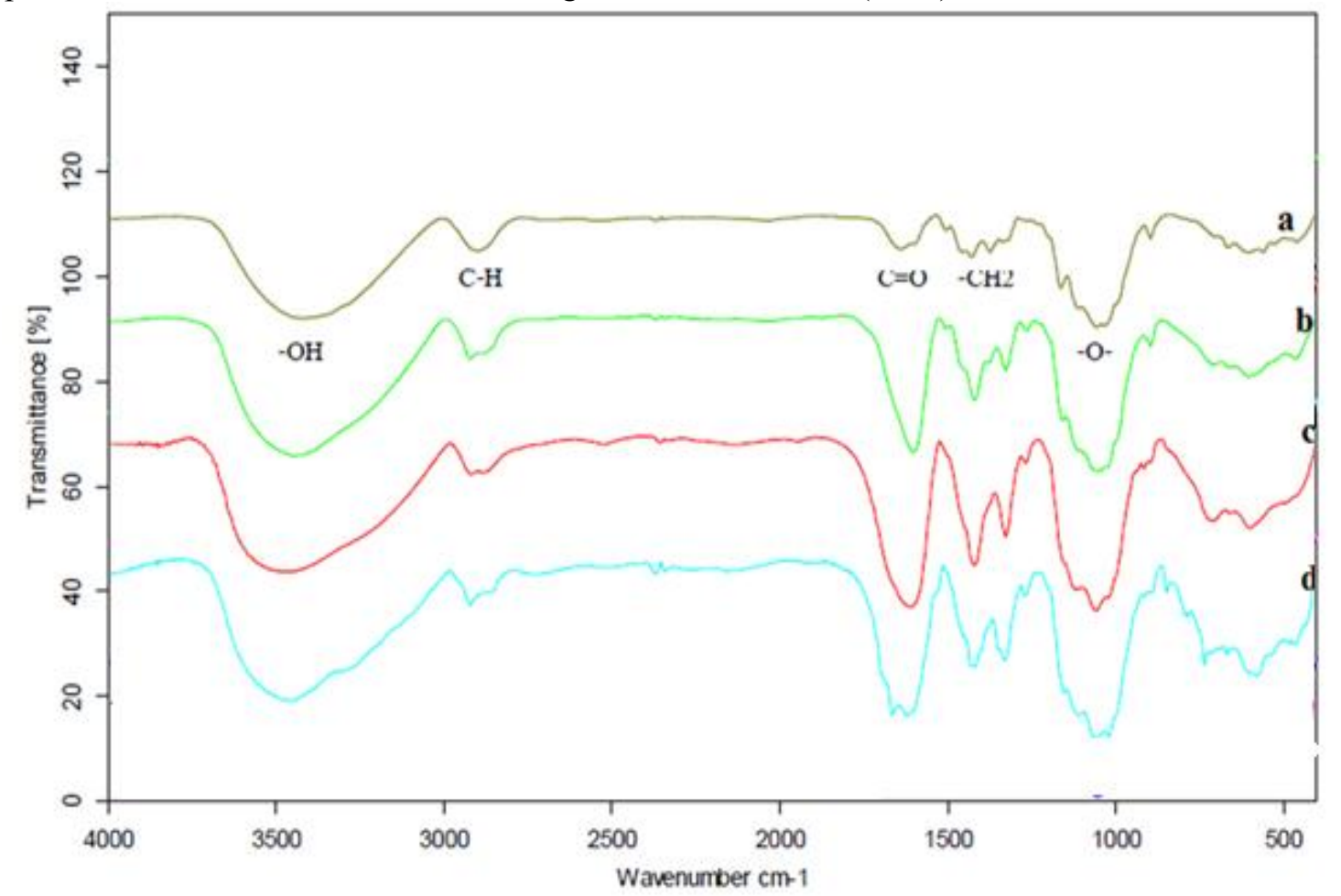

a: Pure cellulose

b: Commercial carboxymethyl cellulose

c: Carboxymethyl cellulose produced from rice bran

d: Carboxymethyl cellulose produced from wheat bran

On the other hand, protein content of the fat-replaced uncooked and cooked beef burger were increased as the replacement level increased. Furthermore, protein content percentage of uncooked beef burger samples were $42.55,44.14,45.26$ and $46.26 \%$ for control sample and those formulated by replace fat with levels $(1.0,1.5$ and $2.0 \%) \mathrm{CMC}_{1}$ produced from rice bran, respectively. Meanwhile, protein content percentage of uncooked beef burger samples containing $\mathrm{CMC}_{2}$ produced from wheat bran were $44.10,45.42$ and 46.41 respectively.

Crude fiber content was affected by fat replacement. Furthermore, it was significantly $(\mathrm{P}<0.05)$ increased by increasing fat replacement levels of $\mathrm{CMC}_{1}$ and $\mathrm{CMC}_{2}$. This increment may be due to high crude

fiber content of $\mathrm{CMC}_{1}$ and $\mathrm{CMC}_{2}$. Data of the present study are in agreement with those found by Youssef et al. (2012) and Gibis et al. (2017).

From the same Table (3) it could be noticed that, as the ratios of fat replacers increased the total carbohydrates of samples were increased with a significant difference in comparison with control beef burger.

Meanwhile, ash content in beef burger formula, it was, no significant differences at $p>0.05$. Also, from the same table, it should be noted that, cooked beef burger have percentages of moisture, ether extract and protein lower than uncooked beef burger with significant differences $(p \leq 0.05)$ between samples. Meanwhile, the opposite were found in case of ash and crude fiber and total carbohydrate increased this also was probably due to the moisture loss during cooking (Essa and Elsebaie, 2018). 
3.5. Effect of replacing fat with different levels of CMC produced from rice and wheat bran on physical properties and feder value

Data in Table (4) showed the physical properties of beef burger containing CMC produced from rice and wheat bran with level (1.0,1.5 and 2.0\%) and control beef burger namely texture index Water Holding Capacity(WHC); Protein-Water Coefficient(PWC), Protein-Water-Fat Coefficient(PWFC)and feder value. The water holding capacity (WHC) of meat products is a very important quality attribute which has an influence on product yield, which in turn has economic implications, but is also important in terms of eating quality. (Chang and Sun, 2008).

From the same table, it could be observed that water holding capacity (WHC) of uncooked beef burger increased by increasing CMC produced from rice and wheat bran with level (1.0,1.5 and 2.0\%).

WHC values of beef burger prepared with CMC produced from rice and wheat bran at different levels ranged from 59.28to $66.24 \%$ compared to $56.47 \%$ for control beef burger, this result is probably due to its ability to absorb large amounts of water. Similarly, (Gibis et al.(2015), Basati and Hosseini(2018) and Guedes-Oliveira et al.(2019) they reported that, the increase in WHC in beef burger containing xanthan gums and carboxymethyl cellulose gums was due to the ability of a meat system to hold water is dependent of the strength of the protein network developed and the capacity of the hydrocolloid to entrap water within it, and the CMC is an anionic water- soluble polymer, which likely interacts with meat proteins.

Generally, The values of protein water coefficient (PWC) and protein water fat coefficient (PWFC) which are considered as indices for tenderness of the prepared beef burger, was given in the same Table, (4).

Table 4: Effect of replacing fat with different levels of carboxymethyl cellulose produced from rice and wheat bran on physical properties and feder value of beef burger formula.

\begin{tabular}{lllllll}
\hline \multicolumn{2}{l}{ Treatments } & WHC \% & Plasticity $\mathbf{c m}^{2}$ & PWC & PWFC & Feder Value \\
\hline Control & & $56.47 \pm 0.14^{\mathrm{d}}$ & $6.34 \pm 0.03^{\mathrm{a}}$ & $0.312 \mathrm{~d} \pm 0.008$ & $0.230 \mathrm{~d} \pm 0.006$ & $2.48 \mathrm{c} \pm 0.065$ \\
\hline \multirow{3}{*}{$\mathbf{C M C}_{1}$} & $\mathbf{1 . 0}$ & $59.80 \pm 0.09^{\mathrm{c}}$ & $5.59 \pm 0.10^{\mathrm{b}}$ & $0.326 \mathrm{c} \pm 0.006$ & $0.241 \mathrm{c} \pm 0.005$ & $2.62 \mathrm{~b} \pm 0.040$ \\
& $\mathbf{1 . 5}$ & $62.97 \pm 0.22^{\mathrm{b}}$ & $4.44 \pm 0.14^{\mathrm{c}}$ & $0.331 \mathrm{~b} \pm 0.008$ & $0.252 \mathrm{~b} \pm 0.007$ & $2.63 \mathrm{~b} \pm 0.078$ \\
& $\mathbf{2 . 0}$ & $66.24 \pm 0.14^{\mathrm{a}}$ & $3.41 \pm 0.13^{\mathrm{d}}$ & $0.345 \mathrm{a} \pm 0.006$ & $0.260 \mathrm{a} \pm 0.002$ & $2.71 \mathrm{a} \pm 0.083$ \\
\hline & $\mathbf{1 . 0}$ & $59.28 \pm 0.10^{\mathrm{c}}$ & $5.49 \pm 0.13^{\mathrm{b}}$ & $0.322 \mathrm{c} \pm 0.006$ & $0.239 \mathrm{c} \pm 0.008$ & $2.61 \mathrm{~b} \pm 0.057$ \\
$\mathbf{C M C}_{2}$ & $\mathbf{1 . 5}$ & $62.39 \pm 0.16^{\mathrm{b}}$ & $4.45 \pm 0.15^{\mathrm{c}}$ & $0.330 \mathrm{~b} \pm 0.005$ & $0.248 \mathrm{~b} \pm 0.007$ & $2.62 \mathrm{~b} \pm 0.031$ \\
& $\mathbf{2 . 0}$ & $65.87 \pm 0.14^{\mathrm{a}}$ & $3.44 \pm 0.19^{\mathrm{d}}$ & $0.341 \mathrm{a} \pm 0.009$ & $0.255 \mathrm{a} \pm 0.008$ & $2.70 \mathrm{a} \pm 0.093$ \\
\hline
\end{tabular}

$\overline{\text { WHC }}=$ Water Holding Capacity; PWC $=$ Protein-Water Coefficient; PWFC $=$ Protein-Water-Fat Coefficient; Each value is an average of three determinations \pm standard division Values followed by the same letter in columns are not significantly different at $\mathrm{P}<0.05$ $\mathrm{CMC}_{1}, \mathrm{CMC}_{2}$ are shown in table (A)

The results show that, the values of PWC and PWFC increased gradually with the increasing of $\mathrm{CMC}$ produced from rice and wheat bran with level (1.0, 1.5 and 2.0\%) comparing to control sample. These results were in agreement with those published by Hassan et al. (2014). Also, it can be observed that, plasticity $\left(\mathrm{cm}^{2}\right)$ value of beef burger enriched with different levels of CMC is decreased gradually with increasing the replacement level of CMC. These results were in agreement with those published Shalaby et al., (2015). Also, Feder values, which is used for assessing the physical properties of meat products, was 2.48 for control sample of burger. Feder values of burger increased gradually with increasing the replacement level of CMC. All values of feder values were kept under 4.0. According to Pearson (1991), the feder number in good quality product should not exceed 4.0. These increments in feder number may be due to the increase in water content as a result to increase the fiber content.

\subsection{Effect of replacing fat with different levels of carboxymethyl cellulose produced from rice and wheat bran on cooking properties and $\mathrm{pH}$ value.}

Regarding cooking measurements (cooking shrinkage, Diameter reduction, cooking yield and cooking loss) which are considered to be one of the most important physical quality changes occurring in beef burger during cooking processes, due to protein denaturation and release of fat and water from beef burger (Oroszvári et al., 2005). 
According to the data in Table (5). There were significant differences $(\mathrm{P}<0.05)$ between beef burger control and all low fat beef burger formulas prepared with carboxymethyl cellulose obtained from rice and wheat bran for cooking properties.

Apparent also from the same Table that, cooking loss of beef burger enriched with different levels of $\mathrm{CMC}_{1}$ andCMC $\mathrm{CM}_{2}$ decreased with increasing the addition levels since beef burger enriched with $\mathrm{CMC}$ had cooking loss values lower than that of control. The highest value of cooking loss was observed with beef burger control $(24.96 \%)$ while, the lowest value observed with low beef burger containing $2.0 \%$ $\mathrm{CMC}_{1}$ produced from rice bran $(16.98 \%)$. This may be related to the fiber content of $\mathrm{CMC}_{1}$ which could influence the cooking loss of the beef burger, since fibers could reduce the water loss during cooking by forming gels as reported by these results are in agreement with those of Gibis et al. (2015).

From the results in this Table, it could be noticed that, cooking yield of beef burger enriched with different levels of $\mathrm{CMC}_{1}$ and $\mathrm{CMC}_{2}$ is increased with increasing the addition levels, since beef burger enriched with $\mathrm{CMC}$ had cooking yield values higher than that of control.

Burger containing $2.0 \% \mathrm{CMC}_{1}$ and $\mathrm{CMC}_{2}$ had the highest cooking yield values while, control had the lowest value. This may be related to the fibers content of $\mathrm{CMC}$ which could influence the cooking yield of the beef burger, since fibers could reduce the water loss during cooking by forming gels as reported by Han et al., (2018)

Preventing shrinkage considers as one of the most important factors to maintaining the quality levels of burgers because some consumers related to shrinkage and adding a high amount of water. Control beef burger sample had a high percentage of shrinkage and diameter reduction percent after cooking process in a comparison with burger integrated with CMC. These results are in conformity with the finding stated by Gibis et al. (2015) and Guedes-Oliveira et al..(2019)

Table 5: Effect of replacing fat with different levels of carboxymethyl cellulose produced from rice and wheat bran on cooking properties and $\mathrm{pH}$ value.

\begin{tabular}{lcccccc}
\hline Treatments & & \% Cooking Loss & \% Cooking yield & $\begin{array}{c}\text { Shrinkage } \\
\text { \% }\end{array}$ & \% Diameterreduction & pH \\
\hline Control & & $24.96 \pm 0.14^{\mathrm{a}}$ & $75.04 \pm 0.11^{\mathrm{a}}$ & $19.90 \pm 0.11^{\mathrm{a}}$ & $16.84 \pm 0.10^{\mathrm{a}}$ & $5.85 \pm 0.16^{\mathrm{a}}$ \\
\cline { 1 - 5 } $\mathbf{C M C}_{1}$ & $\mathbf{1 . 0}$ & $20.71 \pm 0.18^{\mathrm{bc}}$ & $79.29 \pm 0.15^{\mathrm{c}}$ & $14.35 \pm 0.16^{\mathrm{b}}$ & $13.38 \pm 0.11^{\mathrm{b}}$ & $5.70 \pm 0.13^{\mathrm{a}}$ \\
& $\mathbf{1 . 5}$ & $18.43 \pm 0.12^{\mathrm{d}}$ & $81.57 \pm 0.13^{\mathrm{b}}$ & $12.70 \pm 0.09^{\mathrm{c}}$ & $12.55 \pm 0.14^{\mathrm{c}}$ & $5.63 \pm 0.10^{\mathrm{a}}$ \\
& $\mathbf{2 . 0}$ & $16.98 \pm 0.11^{\mathrm{e}}$ & $83.02 \pm 0.16^{\mathrm{ab}}$ & $11.50 \pm 0.11^{\mathrm{d}}$ & $11.16 \pm 0.19^{\mathrm{d}}$ & $5.61 \pm 0.12^{\mathrm{a}}$ \\
\hline \multirow{2}{*}{$\mathbf{C M C}_{\mathbf{3}}$} & $\mathbf{1 . 0}$ & $20.97 \pm 0.16^{\mathrm{bc}}$ & $79.03 \pm 0.12^{\mathrm{c}}$ & $14.39 \pm 0.18^{\mathrm{b}}$ & $13.44 \pm 0.13^{\mathrm{b}}$ & $5.77 \pm 0.10^{\mathrm{a}}$ \\
& $\mathbf{1 . 5}$ & $18.73 \pm 0.13^{\mathrm{c}}$ & $81.27 \pm 0.13^{\mathrm{b}}$ & $13.00 \pm 0.10^{\mathrm{c}}$ & $12.60 \pm 0.19^{\mathrm{c}}$ & $5.69 \pm 0.15^{\mathrm{a}}$ \\
& $\mathbf{2 . 0}$ & $17.05 \pm 0.11^{\mathrm{d}}$ & $82.95 \pm 0.19^{\mathrm{ab}}$ & $11.58 \pm 0.14^{\mathrm{d}}$ & $11.48 \pm 0.15^{\mathrm{d}}$ & $5.49 \pm 0.14^{\mathrm{a}}$ \\
\hline
\end{tabular}

Each value is an average of three determinations \pm standard deviation

Values followed by the same letter in columns are not significantly different at $\mathrm{P}<0.05$

$\mathrm{CMC}_{1}$ and $\mathrm{CMC}_{1}$ are shown in table (A)

The beef burger control had highest values of shrinkage, diameter reduction and cooking loss (19.90, 16.84 and $24.96 \%$ respectively). On the other hand, using $\mathrm{CMC}_{1}$ andCMC 2 at different levels improved the shrinkage, diameter reduction and cooking loss of low fat beef burger in compare with those of high fat beef burger control. These results are in harmony with those of (Gibis et al. (2015) they reported that, less shrinkage, diameter reduction and cooking loss in low-fat lamb patties containing CMC compared with control beef burger. Measuring of $\mathrm{pH}$ value is important due to its effect on several properties of meat products, for example color, shelf-life, texture and water holding capacity ( Hashem et al.,2011). Apparent also from the same table that, no significant differences were noticed in $\mathrm{pH}$ among beef burger control (5.85) and that formulated with different replacement levels of CMC. These results are similar to those reported by Aleson-Carbonell et al., (2005).

\subsection{Effect of replacing fat with different levels of carboxymethyl cellulose produced from rice and wheat bran on Texture Profile Analysis (TPA)}

In the present study, the results of beef burger containing CMC produced from rice and wheat bran with levels $(1.0,1.5$ and $2.0 \%)$ and control beef burger were determined as Hardness, springiness, gumminess, chewiness, and cohesiveness values are presented in Table (6). 
Results showed that, Hardness, cohesiveness, springiness, gumminess, and chewiness values of cooked beef burger significantly at $(\mathrm{P}>0.05)$ decreased with increasing levels $\mathrm{CMC}$ produced from rice and wheat bran. The highest values were noticed in control sample $(18.65,0.47,0.73,8.83$ and 6.41 respectively) while, lowest values was noticed in cooked beef burger containing $2.0 \%$ CMC produced from wheat bran $(17.33,0.37,0.60,6.41$ and 3.85 respectively) compared to all samples the same trend was reported by Han and Bertram (2017)and Guedes-Oliveira et al.(2019). The decrease in hardness may be ascribed to a destabilization of the batter with the addition of CMC and pectin, which upon heating therefore no longer is converted into a coherent protein network (Schuh et al., 2013 and Gibis et al., 2015).

Table 6: Effect of replacing fat with different levels of carboxymethyl cellulose produced from rice and wheat bran on Texture Profile Analysis (TPA)

\begin{tabular}{llccccc}
\hline Treatments & $\begin{array}{c}\text { Hardness } \\
\text { (N/cm2) }\end{array}$ & $\begin{array}{c}\text { Coh } \\
\text { (ratio) }\end{array}$ & $\begin{array}{c}\text { Spr } \\
\text { (cm) }\end{array}$ & $\begin{array}{c}\text { Gum } \\
\text { (N/cm2) }\end{array}$ & $\begin{array}{c}\text { Che } \\
\text { (N/cm2) }\end{array}$ \\
\hline Control & & $18.65 \pm 0.34^{\mathrm{a}}$ & $0.47 \pm 0.07^{\mathrm{a}}$ & $0.73 \pm 0.16^{\mathrm{a}}$ & $8.83 \pm 0.10 \mathrm{a}$ & $6.41 \pm 0.42 \mathrm{a}$ \\
\hline & $\mathbf{1 . 0}$ & $18.50 \pm 0.21 \mathrm{ab}$ & $0.42 \pm 0.09 \mathrm{ab}$ & $0.72 \pm 0.04^{\mathrm{a}}$ & $7.95 \pm 0.33 \mathrm{~b}$ & $5.80 \pm 0.14 \mathrm{~b}$ \\
$\mathbf{C M C}_{1}$ & $\mathbf{1 . 5}$ & $17.86 \pm 0.39^{\mathrm{b}}$ & $0.41 \pm 0.09^{\mathrm{ab}}$ & $0.68 \pm 0.01^{\mathrm{ab}}$ & $7.31 \pm 0.26 \mathrm{c}$ & $4.99 \pm 0.25 \mathrm{c}$ \\
& $\mathbf{2 . 0}$ & $17.41 \pm 0.36^{\mathrm{bc}}$ & $0.38 \pm 0.06^{\mathrm{b}}$ & $0.60 \pm 0.03^{\mathrm{c}}$ & $6.58 \pm 0.10 \mathrm{~d}$ & $3.96 \pm 0.31 \mathrm{~d}$ \\
\hline & $\mathbf{1 . 0}$ & $18.41 \pm 0.29 \mathrm{ab}$ & $0.42 \pm 0.01^{\mathrm{ab}}$ & $0.71 \pm 0.04^{\mathrm{ab}}$ & $7.73 \pm 0.14 \mathrm{~b}$ & $5.49 \pm 0.10 \mathrm{~b}$ \\
$\mathbf{C M C}_{2}$ & $\mathbf{1 . 5}$ & $17.80 \pm 0.11^{\mathrm{b}}$ & $0.39 \pm 0.03^{\mathrm{b}}$ & $0.66 \pm 0.01^{\mathrm{b}}$ & $6.88 \pm 0.18 \mathrm{c}$ & $4.59 \pm 0.34 \mathrm{c}$ \\
& $\mathbf{2 . 0}$ & $17.33 \pm 0.13^{\mathrm{c}}$ & $0.37 \pm 0.01^{\mathrm{b}}$ & $0.60 \pm 0.02^{\mathrm{c}}$ & $6.41 \pm 0.19 \mathrm{~d}$ & $3.85 \pm 0.36 \mathrm{~d}$ \\
\hline
\end{tabular}

Coh $=$ Cohesiveness; Gum $=$ Gumminess; Che $=$ Chewiness; Spr $=$ Springiness

Each value is an average of three determinations \pm standard deviation

Values followed by the same letter in columns are not significantly different at $\mathrm{P}<0.05$

$\mathrm{CMC}_{1}$ and $\mathrm{CMC}_{2}$ are shown in table (A)

\subsection{Sensory evaluation of beef burger containing CMC produced from rice and wheat bran with levels (1.0, 1.5 and 2.0\%) and control beef burger}

Sensory properties of any food product are the major part of important attributes that affect the consumer choice (Salem, 2013).

Sensory properties of beef burger as affected by replacing fat with containing CMC produced from rice and wheat bran with levels (1.0,1.5 and 2.0\%) and control beef burger are shown in Table (7).

Table 7: Effect of replacing fat with different levels of carboxymethyl cellulose extracted from rice and wheat bran on Sensory evaluation.

\begin{tabular}{llllllll}
\hline \multicolumn{2}{l}{ Treatment } & Color (10) & $\begin{array}{l}\text { Taste } \\
(\mathbf{1 0})\end{array}$ & $\begin{array}{l}\text { Odour } \\
(\mathbf{1 0})\end{array}$ & $\begin{array}{l}\text { Texture } \\
(\mathbf{1 0 )}\end{array}$ & $\begin{array}{l}\text { Appearance } \\
\mathbf{( 1 0 )}\end{array}$ & $\begin{array}{l}\text { Overall } \\
\text { Acceptability (10) }\end{array}$ \\
\hline Control & & $8.80 \mathrm{a} \pm 0.36$ & $8.90 \mathrm{a} \pm 0.55$ & $9.0 \mathrm{a} \pm 0.60$ & $8.7 \mathrm{a} \pm 0.52$ & $8.8 \mathrm{a} \pm 0.38$ & $9.0 \mathrm{a} \pm 0.47$ \\
\hline \multirow{3}{*}{$\mathbf{C M C}_{\mathbf{1}}$} & $\mathbf{1 . 0}$ & $8.62 \mathrm{~b} \pm 0.32$ & $8.85 \mathrm{a} \pm 0.67$ & $8.80 \mathrm{a} \pm 0.55$ & $8.53 \mathrm{a} \pm 0.33$ & $8.55 \mathrm{a} \pm 0.51$ & $8.82 \mathrm{a} \pm 0.29$ \\
& $\mathbf{1 . 5}$ & $8.24 \mathrm{~b} \pm 0.30$ & $8.67 \mathrm{a} \pm 0.49$ & $8.61 \mathrm{a} \pm 0.34$ & $8.51 \mathrm{a} \pm 0.52$ & $8.52 \mathrm{a} \pm 0.67$ & $8.63 \mathrm{a} \pm 0.43$ \\
& $\mathbf{2 . 0}$ & $8.09 \mathrm{c} \pm 0.25$ & $8.60 \mathrm{a} \pm 0.48$ & $8.52 \mathrm{a} \pm 0.37$ & $8.42 \mathrm{a} \pm 0.40$ & $8.42 \mathrm{a} \pm 0.42$ & $8.55 \mathrm{a} \pm 0.57$ \\
\hline \multirow{3}{*}{$\mathbf{C M C}_{2}$} & $\mathbf{1 . 0}$ & $8.60 \mathrm{~b} \pm 0.35$ & $8.70 \mathrm{a} \pm 0.59$ & $8.65 \mathrm{a} \pm 0.39$ & $8.55 \mathrm{a} \pm 0.45$ & $8.55 \mathrm{a} \pm 0.36$ & $8.71 \mathrm{a} \pm 0.39$ \\
& $\mathbf{1 . 5}$ & $8.20 \mathrm{bc} 0.23$ & $8.50 \mathrm{a} \pm 0.40$ & $8.50 \mathrm{a} \pm 0.36$ & $8.40 \mathrm{a} \pm 0.53$ & $8.41 \mathrm{a} \pm 0.41$ & $8.52 \mathrm{a} \pm 0.68$ \\
& $\mathbf{2 . 0}$ & $8.08 \mathrm{c} \pm 0.24$ & $8.45 \mathrm{a} \pm 0.32$ & $8.45 \mathrm{a} \pm 0.76$ & $8.40 \mathrm{a} \pm 0.47$ & $8.4 \mathrm{a} \pm 0.49$ & $8.50 \mathrm{a} \pm 0.71$ \\
\hline
\end{tabular}

Each value is an average of three determinations \pm standard division

Values followed by the same letter in columns are not significantly different at $\mathrm{P}<0.05$

$\mathrm{CMC}$ and $\mathrm{CMC} 2$ are shown in table $(\mathrm{A})$

From statistical analysis of these data, it could be noticed that there were no significant difference at $(\mathrm{P}<0.05)$ in all sensory properties between all beef burger formula except color had a significant at $(\mathrm{p} \leq 0.05)$ increased with increasing levels $\mathrm{CMC}$ produced from rice and wheat bran. The highest values were noticed in control beef burger (8.80) while, lowest values was noticed in cooked beef burger at $2.0 \%$ level CMC produced from wheat bran (8.08) compared to all samples This result was agreements with Hassan et al.(2014). Moreover, all beef burger formula containing CMC obtained from rice milling 
by-products produced acceptable samples compared with the control . Ramadan et al. (2016) reported that the cereal fiber is neutral in taste and help to retain moisture and fat leading to producing of a more succulent and juicy meat product.

\section{Conclusion and Recommendations}

- Rice and wheat bran is a cheap and new source of carboxymethyl cellulose production

- Carboxymethyl cellulose produced from rice and wheat bran have phychemical properties that represent the industrial carboxymethyl cellulose.

- Carboxymethyl cellulose, produced from rice and wheat bran improves physical, chemical, cooking and sensory properties of burger.

\section{References}

A.M.S.A., 1995. Research guidelines for cookery, sensory evaluation and instrumental tenderness measurements of fresh beef. American Meat Science Assoc., Chicago, U.S.A., 240.

A.O.A.C., Association of Official Analytical Chemists, 2005. Official Methods of Analysis of the Association of Official Analytical Chemists. 18th Ed. Washington., DC, USA.

Adinugraha, M.P., D.W. Marseno, and Hayadi, 2005. Synthesis and haracterization of sodium carboxymethyl cellulose from cavendish banana pseudostem (Musa cavendishii LAMBERT).Carbohydrate Polymer, 62: 164- 169.

Aleson-Carbonell, L., J. Fernandez-Lopez, J.A. Perez-Alvaez, and V. Kuri, 2005. Characteristics of beef burger as influenced by various types of lemon albedo. Inno. Food Sci. and Emer.Technol., 6: 247-255.

Anderson, E.C. and L.M. Sefa-Dadeh, 2001. Evaluation of modified Rice Starch: A new Excipient for Direct Compaction. Drug Dev. Ind. Pharm. 18: 93-106. ASTM, American Society for Testing and Materials, 2003. Standard Test Methods for Carboxymethyl cellulose, ASTM D, 14392003.

Basati, A. and S.E. Hosseini, 2018. The Effects of Adding Xanthan and Carboxymethyl Cellulose on Cooking and Sensory Characteristics of Soya Burger. J. of Food Biosciences and Tech., Islamic Azad University, Science and Research Branch, 8(1): 59-64.

Bledzki, A.K., A.A. Abdullah, and J. Volk, 2010. Barley Husk and Coconut Shell Reinforced Polypropylene Composites: The Effect of Fiber Physical, Chemical and Surface Properties, Composites Science and Technology, 70: 840- 846.

Bourne, M.C., 2003. Food texture and viscosity: Concept and measurement. Elsevier Press, New Yourk/London.

Chang, Q. and D.W. Sun, 2008. Factors affecting the water holding capacity of red meat products: a review of recent research advances. Crit. Rev. Food Science Nutr., 48(2): 137-59.

Chanput, W., C. Theeraulkait, and S. Nakai, 2009. Antioxidative properties of partially purified barley hordein, rice bran protein fractions and their hydrolysates. J. of Cereal Sci., 49: 422-429.

EI-Seesy, T.A., 2000. Quality and Safety of meat burger patties using "HACCP" System 3. Conference of "The Food Industry at the Serice of Turisum", April 112-14th Shrinkage-Cooking loss Drip loss.

Ejikeme, P.M., 2008. Investigation of physicochemical properties of microcrystalline cellulose from agricultural waste. 1: Orange mesocarp. Cellulose, 15: 141-147.

El-Sharnouby, A.G., M.S. Aleid and M.M. Al-Otaibi, 2012. Nutritional Quality of biscuit supplemented with wheat bran and date palm Fruit (Phoenix dactylifera L.), Food and Nutrition Sciences, 3: 322-328.

Ernest, C.A., G. Lawal, A. Muhammad, I.T. Abdullahi, and M.S. Abdullahi, 2016. Physicochemical Analysis of Carboxymethyl Mango (Mangifera Indica) Starch. IOSR Journal of Applied Chemistry (IOSR-JAC). 9(12): 69-74.

Essa, R.Y. and E.M. Elsebaie, 2018. Effect of Using Date Pits Powder as a Fat Replacer and AntiOxidative Agent on Beef Burger Quality. J. Food and Dairy Sci., Mansoura Univ., 9: 91-96.

Furlán, R.L.T., A.P. Padilla, and M.E. Campderrós, 2014. Development of reduced fat minced meats using inulin and bovine plasma proteins as fat replacers. Meat Science, 96: 762- 768. 
Gibis, M., V. Schuh, K. Allard, and J. Weiss, 2017. Influence of molecular weight and degree of substitution of various carboxymethyl celluloses on unheated and heated emulsion type sausage models. Carbohydrate Polymers, 159: 76-85.

Gibis, M., V. Schuh, and J. Weiss, 2015. Effects of carboxymethyl cellulose (CMC) and microcrystalline cellulose (MCC) as fat replacers on the microstructure and sensory characteristics of fried beef patties. Food Hydrocolloids, 45: 236-246.

Gök, V., L. Akkaya, E. Obuz, and S. Bulut, 2011. Effect of ground poppy seed as a fat replacer on meat burgers. Meat Science, 89, 400-404.

Guedes-Oliveira, J.M., B.R.C. Costa-Lima, D. Oliveira, A. Neto, R. Deliza, C. A. Conte-Junior, and C.F.M. Guimarães, 2019. Mixture design approach for the development of reduced fat lamb patties with carboxymethyl cellulose and inulin. Food Science and Nutrition, 1:1-9.

Han, M. and H.C. Bertram, 2017. Designing healthier comminuted meat products: Effect of dietary fibers on water distribution and texture of a fat-reduced meat model system. Meat Science, 133, $159-165$.

Han, M., M.P. Clausen, M. Christensen, E. Vossen, T. Van Hecke, and H.C. Bertram, 2018. Enhancing the health potential of processed meat: the effect of chitosan or carboxymethyl cellulose enrichment on inherent microstructure, water mobility and oxidation in a meat-based food matrix. Food and Function, 9(7): 4017-4027.

Hashem, Alyaa, M.A., K.M.E. Youssef, M.D. Mostafa, and A.A. Seliem, Magda, 2011. The Influence of Frozen Storage on Physical and Organoleptic Properties of Beef and Low-Fat Beef Burgers. Assiut J. of Agric. Sci., 42 (Special Issue)(The 5th Conference of Young Scientists Fac. of Agric. Assiut Univ. May, 8, 2011), 184-211.

Hassan, A.M., Mona M. Khalil, Rania E. El Gammal and Y.I. El Sherbini, 2014. Chemical, physical and biological characteristics of low fat beef burger with maltodextrin. J. Food and Dairy Sci., Mansoura Univ., 5 (11): $795-811$.

Howard, B.V., J.E. Manson, M.L. Stefanick, S.A. Beresford, G. Frank, B. Jones, R.J. Rodabough, L. Snetselaar, C. Thomson, 1. Tinker, M. Vitolins, and R. Prentice, 2006. Low fat dietary pattern and weight change over 7 years. J. Am. Med. Assoc., 295:39-49.

Hussein A.M.S. and G.E. Ibrahim, 2019. Effects of various brans on quality and volatile compounds of bread. Foods and Raw Materials, 7 (1): 42-50.

Kılınççeker, O. and Ş. Kurt, 2018. Effects of inulin, carrot and cellulose fibers on the properties of raw and fried chicken meatballs. South African J. of Animal Sci., 48(1).

Larrauri, J.A., P. Ruperez, B. Borroto, and S. Saura-Calixto, 1996. Mango peels as a new tropical fiber: preparation and characterization. Lebensm Wiss. u. Technol., 29: 729-733.

Latif, A., T. Anwar, and S. Noor, 2007. Two-step synthesis and characterization of carboxymethyl cellulose from rayon grade wood pulp and cotton linter. Journal of the Chemical Society of Pakistan, 29(2): 143-150.

Manali, C. and B. Dr Savita., 2019. Critical Analysis of Wheat Bran as Therapeutic Source. International Journal of Trend in Scientific Research and Development (IJTSRD), 3 (3):296303.

Mansour, E.H., and A.H. Khalil, 1997. Characteristics of low-fat beef burger as influenced by various types of wheat fibers. Food Research International, 30: 199-205.

Mondal, I.H., M.S. Yeasmin, and M.S. Rahman, 2015. Preparation of food grade carboxymethyl cellulose from corn husk agrowaste. International journal of biological macromolecules, 79: 144-150.

Okhamafe, A.O., A. Igboechi, and T.O. Obaseki, 1991. Celluloses extracted from groundnut shell and rice husk, preliminary physicochemical characterization. Pharm. World J., 8(4): 120- 130.

Oliveira, J.P., G.P. de Bruni, K.O. Lima, S.L.M.E. Halal, G.S. Rosa, A.R.G. daDias, and E.R. Zavareze, 2017. Cellulose fibers extracted from rice and oat husks and their application in hydrogel. Food Chemistry, 221: 153-160.

Oroszvári, B.K., E. Bayod, I. Sjohölm, and E. Tornberg, 2005. The mechanisms controlling heat and mass transfer on frying beef burgers. 2. The influence of the pan temperature and patty diameter. J. of Food Engineering, 71: $18-27$.

Pearson, D., 1970. The chemical analysis of food. National College of Food Technology, University of Reading, Weybridge, Surry. J. and A. Churchill. 
Pearson, D., 1991. The Chemical Analysis of Food. National College of Food Technology, University of Reading. Weybridge. Surry, T. and A. Churchill.

Pushpamalar, V., S.J. Langford, M. Ahmad, and Y.Y. Lim, 2006. Optimization of reaction conditions for preparing carboxymethyl cellulose from sago waste. Carbohydrate Polymers, 64, 312-318.

Rachtanapun, P., N. Mulkarat, and N. Pintajam, 2007. Effect of sodium hydroxide concentration on mechanical properties of carboxymethyl cellulose films from waste of mulberry paper, $5^{\text {th }}$ International Packaging Congress and Exhibition, 22- 24.

Ramadan, R.M., A.M. Sorour, and A.M. Kelany, 2016. Improving oxidative stability of beef burgers under chilled storage using cereal grain fractions. Scientific Papers-Animal Science Series: Lucrări Ştiinţifice - Seria Zootehnie, 65: 183 - 187.

Salem, M.A., A.M. Sorour, and M.A. El-Bana, 2018. Potential antioxidative activity of rice milling byproducts. Menoufia J. Food and Dairy Sci., 3: 1- 13.

Salem, R.H., 2013. Quality characteristics of beef sausages with tomato peel as a color and functional additive during frozen storage. World Applied Sciences, J. 22 (8):1085-1093.

Schuh, V., K. Allard, K. Herrmann, M. Gibis, R. Kohlus, and J. Weiss, 2013. Impact of carboxymethyl cellulose (CMC) and microcrystalline cellulose (MCC) on functional characteristics of emulsified sausages. Meat Science, 93(2): 240-247.

Shalaby, M.T., A.M. Hassn, N.A. El-Boraey and Mona M. ElShahat, 2015. Quality attributes of some sausage like- products. J. Food and Dairy Sci., Mansoura Univ., 6 (2): $101-117$.

Steell, R.G. and J.H. Torrie, 1980. Principles and procedures of statistics.2nd Ed. pp 120. McGraw-Hill, New York, USA.

Tadrus, M.D., 1989. Chemical and Biological Studies on Some Baby Foods. M.Sc. Thesis, Fac. of Agric., Cairo Univ., Egypt.

Togrul, H. and N. Arslan, 2003. Production of carboxymethyl cellulose from sugar beet pulp cellulose and rheological behaviour of carboxymethyl cellulose. Carbohydrate Polymers, 54, 73-82.

Tsolaze, E.A., 1972. The relationship between the tenderness of fish meat and its protein water and protein water fat coefficients. Fish Industry, 48 (7): 68 - 69.

Turhan, S., I. Sagir, and N.S. Ustun, 2005. Utilization of hazelnut pellicle in low-fat beef burgers. Meat Science, 71, 312-316.

Ulu, H., 2004. Effect of wheat flour, whey protein concentrate and soya protein isolate on oxidative processes and textural properties of cooked meatballs. Food Chemistry, 87: 523-529.

Youssef, K.M.E., M.D. Mostafa, Seliem, Magda, A.A. and Hashem Alyaa, M.A., 2012. Total lipid fractions and fatty acids composition of low-fat beef burger. Food and Public Health, 2(2): 3439.

Zhou, S., X. Liu, Y. Guo, Q.Wang, D. Peng and L. Cao., 2010. Comparison of the immunological activities of arabinoxylans from wheat bran with alkali and xylanase-aid extraction. Carbohydrate Polymer, 81: 784-789. 